\title{
FEMALE SEXUAL FUNCTION OF HEALTHY WOMEN IN EASTERN CROATIA
}

\author{
Iva Milić Vranješ ${ }^{1,2}$, Jelena Jakab ${ }^{1,3}$, Marul Ivandić ${ }^{1,4}$, Siniša Šjanovićc ${ }^{1,2}$ and Lada Zibar ${ }^{1,5}$ \\ ${ }^{1}$ Faculty of Medicine, Josip Juraj Strossmayer University of Osijek, Osijek, Croatia; \\ ${ }^{2}$ Department of Gynecology and Obstetrics, Osijek University Hospital Centre, Osijek, Croatia; \\ ${ }^{3}$ Department of Pathophysiology, Faculty of Dental Medicine and Health, \\ Josip Juraj Strossmayer University of Osijek, Osijek, Croatia; ${ }^{4}$ Department of Cardiology, \\ Osijek University Hospital Centre, Osijek, Croatia; \\ ${ }^{5}$ Department of Nephrology, Osijek University Hospital Centre, Osijek, Croatia
}

\begin{abstract}
SUMMARY - The aim was to evaluate sexual function of healthy women in Croatia and the possible impact of depression, anxiety, and sociodemographic factors. A total of 204 healthy women filled in a basic sociodemographic questionnaire, the Patient Health Questionnaire-9, Anxiety Disorder-7, and Female Sexual Function Index (FSFI). Almost half of study subjects (47.1\%) reported at least some degree of sexual dysfunction defined as an FSFI score lower than 26.55. Study results suggest sexual dysfunction of women in Croatia as a still unrecognized problem. More room in research and in the public must be given to this issue.
\end{abstract}

Key words: Female; Croatia; Sexual dysfunction, physiological; Depression; Anxiety; Patient health questionnaire

\section{Introduction}

Sexual function is an integral component of every woman's life. The impact of sexual health on overall life satisfaction and quality of life (QOL) is increasingly recognized. Female sexual function problems are multidimensional, associated with general health, affected by medication use or substance abuse, but also inseparable from relationship characteristics, cultural influences, socioeconomic status, and religious beliefs ${ }^{1}$. Sexual problems have a serious impact on mood, selfesteem, and QOL. They may lead to emotional distress, relationship problems, divorce, or they may even affect reproduction ${ }^{2}$. Sexual dysfunction (SD) is an important public health issue. According to epidemiological studies, sexual problems are widespread among women of all ages ${ }^{3-6}$, ranging from $19 \%$ to $63 \% \%^{7}$. Fe-

Correspondence to: Jelena Jakab, MD, Department of Pathophysiology, Faculty of Dental Medicine and Health, Josip Juraj Strossmayer University of Osijek, Crkvena 21, HR-31000 Osijek, Croatia E-mail: jelena.jakab@fdmz.hr

Received October 15, 2018, accepted November 25, 2019 male sexual dysfunction (FSD) is still largely unexplored, and actual prevalence figures vary widely due to differences in diagnostic criteria ${ }^{8}$. The International Consensus Development Conference on Female Sexual Dysfunctions classified FSD into four disorders ${ }^{9}$ and developed the Female Sexual Function Index (FSFI), which assesses sexual function within six domains: desire, arousal, orgasm, pain, lubrication, and satisfaction ${ }^{10}$. Accurate estimates of the prevalence/incidence of FSD and identifying risk factors are important for prevention efforts and treatment planning. The prevalence of FSD in Europe and the United States has been investigated in many recent studies; however, data from Croatia on the prevalence and risk factors for this condition are rare. To the authors' knowledge, only two research studies on female sexual problems in Croatia taking into account different domains of sexual function were conducted, one of them providing information on the prevalence of sexual problems and related risk factors in a community sample in the Croatian capital of $Z_{\text {agreb }}{ }^{1}$, while the other investigated prevalence of sexual health difficulties among women 
aged 18-35 across all 21 counties of six major regions of Croatia ${ }^{11}$. There were no studies using the FSFI, but data relied solely on the participants' statement that they had difficulties in different aspects of sexual functioning.

The aim of this study was to assess the level of sexual functioning and the prevalence of SD in healthy, sexually active women in eastern Croatia.

\section{Materials and Methods}

\section{Participants}

A cross-sectional study was conducted on 204 healthy female subjects aged 18-65 years (median age 42 , IQR 32-51) from eastern Croatia as part of a larger study in which sexual function will be assessed in various clinical samples. Participants were gathered among acquaintances of the authors. Thus, the sample was a convenient one. Although a precise response rate was not determined, there were almost no declines to participate in the study. Women with severe somatic or psychiatric conditions, pregnant women, those under 18 and over 70 years of age, as well as those who declined to give their signed consent were excluded from the study. The study was approved by the Ethics Committees of the Osijek Faculty of Medicine and Osijek University Hospital Centre, and the study protocol conformed to the provisions of the Declaration of Helsinki. All study participants provided their written informed consent.

\section{Questionnaire}

The participants were presented a self-administered questionnaire consisting of four parts. In the first part, the participants were asked about their basic sociodemographic characteristics: age, current relationship status, type of relationship (marriage, extramarital relationship, same-sex partnership, and none of the above), place of residence (city, town, suburb, and village), education and parity.

The second part consisted of the Patient Health Questionnaire-9 (PHQ-9). PHQ-9 is a validated instrument with high sensitivity and specificity, consisting of nine questions that are answered on a Likert scale, each providing information on one of the nine criteria for depression as defined by Diagnostic and Statistical Manual of Mental Disorders, Fourth Edition (DSM-IV) $)^{12-15}$.
The third part consisted of the Generalized Anxiety Disorder-7 (GAD-7) questionnaire. GAD-7 is a validated instrument developed to be used as an orientational evaluation of the anxiety symptoms. It consists of seven questions answered on a Likert scale ${ }^{16-18}$.

The fourth part included the FSFI, a validated 19item questionnaire that measures six domains of female sexual function (desire, arousal, lubrication, orgasm, satisfaction, and pain $)^{19}$ in four weeks before the examination. The answers vary from 0 (no sexual activity) or 1 to 5 . Individual domain scores are defined as the sum of the scores of the questions pertaining to the domain, multiplied by a factor provided by the authors of the scale. Total FSFI is obtained by adding the six domain scores. Total score ranges from 2 to 36, with higher scores signifying better sexual function. A cutoff score of 26.55, as suggested by Wiegel et al., was used to determine $\mathrm{SD}^{20}$.

Since all the participants spoke Croatian, validated Croatian versions of the PHQ-9 and GAD-7 were used. Since, to the authors' knowledge, Croatian version of the FSFI had not been previously prepared, a team of translators did translation using a modified back-translation method proposed by several authors ${ }^{21-24}$. Two fluently bilingual physicians each translated the FSFI into Croatian. The two versions were compared and synthesized into a single translation by a team of three bilingual physicians. The aforementioned translation was then back-translated into English by a Croatian translator with master degree in English language and literature. The back-translation was then compared with the English original to assure linguistic validity by several fluently bilingual medical professionals and translators.

\section{Statistical analysis}

The sample size required to maintain a power of $80 \%$ and alpha error probability of 0.05 was calculated using the $G^{*}$ Power 3.1 software ${ }^{25,26}$. KolmogorovSmirnov test was used to test the normality of data distribution. Since all scalar variables deviated from normal distribution, nonparametric tests were used. Numerical data were expressed as median and interquartile range (IQR). To compare the means of two or more independent groups, Mann-Whitney and Kruskal-Wallis test was used, respectively. Correlation between variables was assessed with the Spearman's rank-order correlation coefficient. The level of statisti- 
cal significance was set at $\mathrm{p}<0.05$. Multivariate analysis was performed to determine independent association of variables with the FSFI score. The analysis was conducted using the SPSS software (ver. 16.0, SPSS Inc., Chicago, IL, USA).

\section{Results}

Basic sociodemographic characteristics of the participants are shown in Table 1.

As shown in Table 1, 32 participants were not in a relationship in the month prior to the examination. Table 2 shows differences between the two groups divided according to relationship status. No differences were found in depression or anxiety score. As expected, significant differences were recorded for sexual function. Only the participants having reported a relationship were included in further analysis.

When considering the cut-off scores for PHQ-9, GAD-7 and FSFI, study participants were divided as follows: 110 (53.9\%) subjects had no or very low level of anxiety, $56(27.5 \%)$ had mild, 31 (15.2\%) moderate and three $(1.5 \%)$ subjects severe anxiety. Depressive symptoms were absent in 157 (77\%) subjects, 34 (16.7\%) had mild depressive symptoms, ten (4.9\%) moderate and two (1\%) subjects severe depressive symptoms.

In the group of women in a relationship, 91 (52.9\%) had FSFI score over 26.55, indicating normal sexual function, whereas $81(47.1 \%)$ showed some degree of sexual dysfunction. Sixteen (9.3\%) women reported having had no sexual activity in the month prior to the examination.

There were no significant differences in age $(\mathrm{p}=0.4$, Kruskal-Wallis test), PHQ-9 ( $\mathrm{p}=0.874$, Kruskal-Wallis test), GAD-7 ( $\mathrm{p}=0.571$, Kruskal-Wallis test) or FSFI score ( $\mathrm{p}=0.063$, Kruskal-Wallis test) according to the place of residence.

There were no significant differences in PHQ-9 ( $p=0.118$, Kruskal-Wallis test), GAD-7 ( $p=0.578$, Kruskal-Wallis test) or FSFI score ( $\mathrm{p}=0.073$, KruskalWallis test) between the groups divided according to the level of education. However, there was a significant age difference according to the level of education, i.e. younger women had higher levels of education.

There was no significant difference in FSFI score according to the number of children ( $p=0.222$, Kruskal-Wallis test), but there was a weak significant nega-
Table 1. Sociodemographic characteristics of study participants

\begin{tabular}{|l|l|}
\hline & $\mathrm{N}=204$ \\
\cline { 2 - 2 } Current relationship status & $\mathrm{n}(\%)$ \\
In a relationship & $172(84.3)$ \\
Not in a relationship & $32(15.7)$ \\
\hline Type of relationship & \\
Marriage & $126(61.8)$ \\
Extramarital relationship & $29(14.2)$ \\
Same-sex partnership & 0 \\
None of the above & $49(24)$ \\
\hline Place of residence & \\
City & $109(53.4)$ \\
Small town & $36(17.6)$ \\
Suburb & $22(10.8)$ \\
Village & $37(18.1)$ \\
\hline Level of education & \\
Elementary school & $11(5.4)$ \\
High school & $107(52.5)$ \\
Bachelor's degree & $15(6.9)$ \\
Four-year college degree, or higher & $68(33.3)$ \\
\hline Number of children & \\
0 & $60(29.4)$ \\
1 & $41(20.1)$ \\
2 & $71(34.8)$ \\
3 & $18(8.8)$ \\
4 & $8(3.9)$ \\
5 & $3(1.5)$ \\
6 & $3(1.5)$ \\
\hline Have you undergone serious surgery & \\
in your lifetime? & $33(16.2)$ \\
Yes & $171(83.8)$ \\
No & \\
\hline
\end{tabular}

tive correlation between the number of children and FSFI score (Spearman's rho=-0.166, $\mathrm{p}=0.029$ ).

A significant difference was found in the level of anxiety according to the number of children $(p=0.04$, Kruskal-Wallis test), but there was no significant correlation between these variables (Spearman's rho $=0.086$, $\mathrm{p}=0.222$ ). A significant age difference was also found according to the number of children $(\mathrm{p}<0.001$, KruskalWallis test), with age positively correlating with the number of children (Spearman's rho=0.596, $\mathrm{p}<0.001$ ). 
Table 2. Differences in PHQ-9, GAD-7, FSFI scores and age according to participant relationship status one month prior to the examination $(N=204)$

\begin{tabular}{|l|l|l|l|l|}
\hline \multirow{2}{*}{} & \multicolumn{4}{|c|}{ Median (IQR) } \\
\cline { 2 - 5 } & PHQ-9 & GAD-7 & FSFI & Age (yrs) \\
\hline Not in a relationship $(\mathrm{n}=32)$ & $7.5(4.25-10)$ & $6(3.25-9)$ & $5.2(2.6-9.6)$ & $49.5(25-57.75)$ \\
In a relationship $(\mathrm{n}=172)$ & $5(2.25-9)$ & $5(2.25-8)$ & $27.85(22.7-31)$ & $42(33-50)$ \\
p value (Mann-Whitney test) & 0.062 & 0.247 & $<0.001$ & 0.565 \\
\hline
\end{tabular}

PHQ-9 = Patient Health Questionnaire-9; GAD-7 = Generalized Anxiety Disorder-7; FSFI = Female Sexual Function Index; IQR = interquartile range

Table 3. FSFI domains and total FSFI scores $(N=172)$

\begin{tabular}{|l|l|}
\hline & Median (IQR) \\
\hline Desire & $3.6(3-3.6)$ \\
Arousal & $4.2(3.3-4.8)$ \\
Lubrication & $4.95(3.6-5.7)$ \\
Orgasm & $4.8(3.6-6)$ \\
Satisfaction & $5.2(4-6)$ \\
Pain & $6(4.4-6)$ \\
FSFI & $27.85(22.7-31)$ \\
\hline
\end{tabular}

FSFI = Female Sexual Function Index; IQR $=$ interquartile range
There were no differences in PHQ-9 scores between the groups divided according to the number of children ( $\mathrm{p}=0.351$, Kruskal-Wallis test).

There were no differences in age ( $\mathrm{p}=0.49$, KruskalWallis test), PHQ-9 ( $\mathrm{p}=0.7$, Kruskal-Wallis test) or GAD-7 ( $\mathrm{p}=0.164$, Kruskal-Wallis test) score related to the subjects' having had sexual activity in the month prior to the examination or not.

A significant difference in the FSFI score was found according to the type of relationship ( $\mathrm{p}=0.001$, KruskalWallis test), with married women (median 26.1, IQR

Table 4. Correlations (Spearman's rho) of age, GAD-7, PHQ-9 and FSFI domain, and total scores of participants in relationship $(N=172)$

\begin{tabular}{|c|c|c|c|c|c|c|c|c|c|}
\hline & GAD-7 & PHQ-9 & Desire & Arousal & Lubrication & Orgasm & Satisfaction & Pain & FSFI \\
\hline Age & -0.023 & -0.035 & $-0.349^{* * *}$ & $-0.36^{* *}$ & $-0.215^{* *}$ & $-0.241^{* *}$ & $-0.205^{* *}$ & -0.056 & $-0.299^{* * *}$ \\
\hline GAD-7 & & $0.827^{\text {*at }}$ & $-0.193^{*}$ & $-0.224^{* *}$ & -0.094 & -0.139 & $-0.19^{*}$ & $-0.151^{*}$ & $-0.173^{*}$ \\
\hline PHQ-9 & & & $-0.219^{* *}$ & $-0.231^{* *}$ & -0.126 & $-0.219^{* * *}$ & $-0.257^{* *}$ & $-0.22^{* * *}$ & $-0.23^{* *}$ \\
\hline Desire & & & & $0.598^{* *}$ & $0.419^{* * *}$ & $0.354^{* *}$ & $0.456^{* *}$ & $0.271^{* *}$ & $0.609^{* *}$ \\
\hline Arousal & & & & & $0.645^{* * *}$ & $0.58^{* *}$ & $0.547^{* *}$ & $0.516^{* *}$ & $0.771^{* *}$ \\
\hline Lubrication & & & & & & $0.723^{* *}$ & $0.667^{* * *}$ & $0.535^{* * *}$ & $0.865^{* * *}$ \\
\hline Orgasm & & & & & & & $0.701^{* *}$ & $0.458^{* *}$ & $0.84^{* *}$ \\
\hline Satisfaction & & & & & & & & $0.463^{* *}$ & $0.838^{* *}$ \\
\hline Pain & & & & & & & & & $0.601^{* *}$ \\
\hline
\end{tabular}

PHQ-9 = Patient Health Questionnaire-9; GAD-7 = Generalized Anxiety Disorder-7; FSFI = Female Sexual Function Index; ${ }^{*}<0.05$; ${ }^{* *} \mathrm{p}<0.01$

Table 5. Correlations (Spearman's rho) of age, GAD-7 and $P H Q-9$ scores $(N=204)$

\begin{tabular}{|l|l|l|}
\hline & GAD-7 & PHQ-9 \\
\hline Age (yrs) & 0.048 & -0.042 \\
GAD-7 & & $0.823^{*}$ \\
\hline
\end{tabular}

* $\mathrm{p}<0.001$

GAD-7 = Generalized Anxiety Disorder-7; PHQ-9 = Patient Health Questionnaire-9;
21.6-30.5) having lower scores than those in extramarital relationships (median 31, IQR 25.45-32.55) and those stating that they were in other types of relationship (median 30.15, IQR 25.2-32.75) (Table 2).

There was a significant age difference between the groups based on marital status ( $\mathrm{p}<0.001$, Kruskal-Wallis test). Married women were oldest (median 46, IQR 38-53), women in extramarital relationships were sec- 
ond oldest (median 32, IQR 25.5-42.5), and those in other kinds of relationship were youngest (median 26, IQR 20-36.5).

Median scores of the individual domains of the FSFI questionnaire, as well as median of total FSFI scores are presented in Table 3.

Tables 4 and 5 illustrate correlations between scalar variables.

A stepwise multiple linear regression analysis was performed to determine how different variables affected the FSFI score. The number of children, GAD-7 and PHQ-9 scores were excluded from analysis. A model was created taking into account age and relationship status. The model explained $34.2 \%$ of variance as determined by the adjusted R Square (standard error (SE) 5.93). ANOVA suggested that the model had a significant explanatory power, $\mathrm{F}=50.069, \mathrm{p}<0.001, \mathrm{df}=2$.

Both independent variables included in the model significantly affected the FSFI score, relationship status had unstandardized B 11.736, SE 1.236, $\mathrm{t}=9.493$, $\mathrm{p}<0.001$, while age had unstandardized B -0.090 , SE $0.037, \mathrm{t}=-2.419, \mathrm{p}=0.017$.

\section{Discussion}

Female sexual dysfunction is defined as a disorder of libido, arousal, orgasm, physical pleasure, and pain related to sexual intercourse ${ }^{27,28}$. SD has a significant impact on QOL and personal relationships, including aspects such as marriage satisfaction and social performance ${ }^{29}$. The purpose of our analysis was to provide insights into the female sexual function in eastern Croatia.

When using the cut-off score of 26.55 suggested by Wiegel et al. ${ }^{20}, 47.1 \%$ of study participants showed some degree of $\mathrm{SD}^{30}$. This prevalence is similar to that found in similar studies conducted in Croatia, where $47 \%{ }^{11}$ and $37 \%{ }^{1}$ of women were found to have some difficulties. However, direct comparison of our results with other results from Croatia was not possible due to different measures used in those studies. Our results are also in line with the results of research in other areas. A study in the USA found the prevalence of FSD among women in the general population to be $43 \%{ }^{30}$, and another study in England reports it to be $41 \%{ }^{31}$.

Since our sample was a convenient one, with the participants gathered from the pool of the authors' acquaintances, and since there were virtually no declines to participate in the study, we postulated that our results would be somewhat lower than those reported in the literature. Response rates in similar studies are most commonly below $50 \% \%^{1,32}$, and the women willing to participate are presumably more open, liberal and with better sexual function, whereas those who decline to participate presumably have more difficulties with their sexual function, and are therefore less likely to answer questions pertaining to their sexual life ${ }^{33}$. According to the Census of Population, Households, and Dwellings 2011, 86.28\% of Croatian citizens were Catholic. Sexually restrictive religious morality can be responsible for reduction in the ability to focus on sexual feelings and sensations ${ }^{34}$. Such norms can block sexual expression by instilling feelings of guilt, at least in women.

Married women in our study had lower FSFI scores than both the women in extramarital relationships and those in other types of relationships, which is discordant with the results of both previous studies conducted in Croatia. The fact that partner communication and marriage significantly lower the odds of having sexual difficulties has been reported in many studies ${ }^{3,5}$, confirming the importance of relationship quality for female sexual health. The possible reason for the results in our sample might be age difference between the groups, with married women being oldest, and it is well documented that age leads to a decline in sexual function ${ }^{5,30}$. This was also confirmed in our study by the results of multiple linear regression analysis, which showed that age and relationship status explained $34.2 \%$ of variance with a significant explanatory power.

We found no significant differences in sexual function based on the number of children. This is in contrast with the findings of other studies, where women with small children were more likely to report sexual problems ${ }^{11,35}$.

Loss of interest, reduction in energy and inability to experience pleasure are characteristics of depression that may produce difficulties in sexual relationships. One study showed that as much as $72 \%$ of patients with unipolar depression reported loss of sexual interest $^{36}$. Furthermore, comparative studies found higher levels of SD in depressed patients than in healthy controls ${ }^{36-38}$. Although the specific type of sexual dysfunction varies in incidence, the most common complaint is loss of sexual desire, as was the case in our sample. In our sample, depression negatively correlated with every domain of sexual function, except for lubrication, which was expected and previously documented. 
Aging affects a woman's sexual function through a range of hormonal and physiological changes. There is a number of cross-sectional studies providing strong evidence that sexual function declines with age $e^{5,30,39}$. On the other hand, SDs do not change or even decline with age ${ }^{4,40-42}$. This is interesting because one would expect an increase in SD given the evidence for sexual function decline with age. However, the key may be changes in sexually related distress, since the importance of sex decreases in older women ${ }^{43}$.

According to some studies, the frequency of SD in postmenopausal women was up to $81 \% \%^{44,45}$, which was accordant to the study by Peeyananjarassri et al., who found that $82.2 \%$ of postmenopausal women suffered from $\mathrm{SD}^{46}$. Our results are in line with those reported in the literature. There was a negative correlation between the FSFI scores and all its domains except for pain, and age.

A study performed in the USA found that approximately $23 \%$ of postmenopausal women reported problems with feeling sexual desire, $13 \%$ had arousal problems, and even $64 \%$ of postmenopausal women had not experienced orgasm during the intercourse. About 22\% had no lubrication during sexual activity ${ }^{47}$.

Even in early psychodynamic formulations, SD anxiety was seen as one of the key factors leading to and promoting $\mathrm{SD}^{48}$. In our sample, the anxiety levels negatively correlated with sexual function, thus giving additional support to previous findings.

The study suffered from some limitations, as follows: our sample size was too small to represent total population of eastern Croatia, and the results presented here are preliminary results of a larger study. Much larger, multicenter studies are needed to provide better insight into the situation of sexual function of women in Croatia. The sample was a convenient one, with participants being gathered from the pool of the authors' acquaintances. Although this could be considered a limitation, the response rate was far higher than in similar studies. Questions about the participants' religious views, character, and additional questions about their relationships and sexual behavior beyond the scope of the FSFI might shed more light on the issue of the high prevalence of SD in Croatian women.

\section{Conclusion}

In this cross-sectional study, we questioned healthy women from eastern Croatia about their sexual func- tion and other related parameters. Almost half of our subjects (47.1\%) reported at least some degree of SD defined as an FSFI score lower than 26.55. Lower levels of sexual function were present in older women and those who showed higher levels of anxiety and depressive symptoms. Our results clearly suggest a great problem that is still unrecognized, i.e. SD of women in Croatia. This issue certainly requires more room in research and public sphere. Medical professionals should not neglect this aspect of a woman's life, so as to help the woman increase her sense of wellbeing, self-esteem and QOL.

\section{References}

1. Stulhofer A, Gregurovic M, Pikic A, Galic I. Sexual problems of urban women in Croatia: prevalence and correlates in a community sample. Croat Med J. 2005 Feb;46(1):45-51. PubMed PMID: 15726675.

2. Ponholzer A, Roehlich M, Racz U, Temml C, Madersbacher S. Female sexual dysfunction in a healthy Austrian cohort: prevalence and risk factors. Eur Urol. 2005 Mar;47(3):366-74, http: //dx.doi.org/10.1016/j.eururo.2004.10.005. PubMed PMID: 15716203 .

3. Heiman JR. Sexual dysfunction: overview of prevalence, etiological factors, and treatments. J Sex Res. 2002 Feb;39(1): 73-8, http://dx.doi.org/10.1080/00224490209552124. PubMed PMID: 12476261.

4. Johnson SD, Phelps DL, Cottler LB. The association of sexual dysfunction and substance use among a community epidemiological sample. Arch Sex Behav. 2004 Feb;33(1):55-63, http:// dx.doi.org/10.1023/B:ASEB.0000007462.97961.5a. PubMed PMID: 14739690.

5. Bancroft J, Loftus J, Long JS. Distress about sex: a national survey of women in heterosexual relationships. Arch Sex Behav. 2003 Jun;32(3):193-208, http://dx.doi.org/10.1023/a:10234 20431760. PubMed PMID: 12807292.

6. Zavoreo I, Grzincic T, Preksavec M, Madzar T, Basic Kes V. Sexual dysfunction and incidence of depression in multiple sclerosis patients. Acta Clin Croat. 2016;55:402-6, https://doi. org/10.20471/acc.2016.55.03.08.

7. Rosen RC, Taylor JF, Leiblum SR, Bachmann GA. Prevalence of sexual dysfunction in women: results of a survey study of 329 women in an outpatient gynecological clinic. J Sex Marital Ther. 1993;19(3):171-88, https://doi.org/10.1080/009262393 08404902. PubMed PMID: 8246273.

8. Amidu N, Owiredu WK, Woode E, Addai-Mensah O, Quaye L, Alhassan A, et al. Incidence of sexual dysfunction: a prospective survey in Ghanaian females. Reprod Biol Endocrinol. 2010 Sep;8:106, https://doi.org/10.1186/1477-7827-8-106. PubMed PMID: 20809943; PubMed Central PMCID: PMC2936896. 
9. Basson R, Berman J, Burnett A, Derogatis L, Ferguson D, Fourcroy J, et al. Report of the international consensus development conference on female sexual dysfunction: definitions and classifications. J Urol. 2000 Mar;163(3):888-93. PubMed PMID: 10688001.

10. Blümel JE, Chedraui P, Baron G, Belzares E, Bencosme A, Calle A, et al. Sexual dysfunction in middle-aged women: a multicenter Latin American study using the Female Sexual Function Index. Menopause. 2009 Nov-Dec;16(6):1139-48, https: //doi.org/10.1097/gme.0b013e3181a4e317. PubMed PMID: 19458559.

11. Stulhofer A, Kuljanic K, Buzina D. Sexual health difficulties in a population-based sample of Croatian women aged 18-35 and the effects of the dual (career and motherhood) role. J Sex Med. 2011 May;8(5):1314-21, https://doi.org/10.1111/j.1743-6109. 2010.02100.x. PubMed PMID: 21054803.

12. Löwe B, Kroenke K, Herzog W, Gräfe K. Measuring depression outcome with a brief self-report instrument: sensitivity to change of the Patient Health Questionnaire (PHQ-9).J Affect Disord. 2004 Jul;81(1):61-6, https://doi.org/10.1016/S01650327(03)00198-8. PubMed PMID: 15183601.

13. Pinto-Meza A, Serrano-Blanco A, Peñarrubia MT, Blanco E, Haro JM. Assessing depression in primary care with the PHQ-9: can it be carried out over the telephone? J Gen Intern Med. 2005 Aug;20(8):738-42, https://doi.org/10.1111/j.1525 -1497.2005.0144.x. PubMed PMID: 16050884; PubMed Central PMCID: PMC1490180.

14. Kroenke K SR, Williams JBW. The PHQ-9.J Gen Intern Med. 2001;16(9):606-13, https://doi.org/10.1046/j.1525-1497.2001. 016009606.x

15. Kroenke K SR. The PHQ-9: a new depression diagnostic and severity measure. Psychiatr Ann. 2002;32(9):509-15.

16. Donker T, van Straten A, Marks I, Cuijpers P. Quick and easy self-rating of Generalized Anxiety Disorder: validity of the Dutch web-based GAD-7, GAD-2 and GAD-SI. Psychiatry Res. 2011 Jun;188(1):58-64, https://doi.org/10.1016/j.psychres.2011.01.016. PubMed PMID: 21339006.

17. Swinson RP. The GAD-7 scale was accurate for diagnosing generalised anxiety disorder. Evid Based Med. 2006 Dec; 11(6):184, https://doi.org/10.1136/ebm.11.6.184. PubMed PMID: 17213178.

18. Ruiz MA, Zamorano E, García-Campayo J, Pardo A, Freire O, Rejas J. Validity of the GAD-7 scale as an outcome measure of disability in patients with generalized anxiety disorders in primary care. J Affect Disord. 2011 Feb;128(3):277-86, https://doi. org/10.1016/j.jad.2010.07.010. PubMed PMID: 20692043.

19. Rosen R, Brown C, Heiman J, Leiblum S, Meston C, Shabsigh $\mathrm{R}$, et al. The Female Sexual Function Index (FSFI): a multidimensional self-report instrument for the assessment of female sexualfunction.J Sex MaritalTher.2000Apr-Jun;26(2):191-208, https://doi.org/10.1080/009262300278597. PubMed PMID: 10782451.

20. Wiegel M, Meston C, Rosen R. The female sexual function index (FSFI): cross-validation and development of clinical cut- off scores. J Sex Marital Ther. 2005 Jan-Feb;31(1):1-20, https:// doi.org/10.1080/00926230590475206. PubMed PMID: 1584 1702.

21. Regmi K, Naidoo J, Pilkington P. Understanding the processes of translation and transliteration in qualitative study. Int J Qual Methods. 2010;9(1):16-26, https://doi.org/10.1177/1609406 91000900103

22. Ozolins U. Back translation as a means of giving translators a voice. Int J Translat Interpret Res. 2009;1(2):1-13.

23. Brislin RW. Back-translation for cross-cultural research. J Cross Cultural Psychol. 1970;1(3):185-216, https://doi.org/ 10.1177/135910457000100301

24. Sperber AD. Translation and validation of study instruments for cross-cultural research. Gastroenterology. 2004;126:124-8, https://doi.org/10.1053/j.gastro.2003.10.016

25. Faul F, Erdfelder E, Lang AG, Buchner A. G*Power 3: a flexible statistical power analysis program for the social, behavioral, and biomedical sciences. Behav Res Methods. 2007 May; 39(2):175-91, https://doi.org/10.3758/bf03193146. PubMed PMID: 17695343.

26. Faul F, Erdfelder E, Buchner A, Lang AG. Statistical power analyses using $G^{*}$ Power 3.1: tests for correlation and regression analyses. Behav Res Methods. 2009 Nov;41(4):1149-60, https:// doi.org/10.3758/BRM.41.4.1149. PubMed PMID: 19897823.

27. Ibrahim ZM, Ahmed MR, Sayed Ahmed WA. Prevalence and risk factors for female sexual dysfunction among Egyptian women. Arch Gynecol Obstet. 2013 Jun;287(6):1173-80, https://doi.org/10.1007/s00404-012-2677-8. PubMed PMID: 23274790.

28. Starc A, Jukic T, Poljsak B, Dahmane R. Female sexual function and dysfunction: a cross-national prevalence study in Slovenia. Acta Clin Croat. 2018;57:52-60, https://doi.org/10.20471/ acc.2018.57.01.06

29. Direkvand-Moghadam A, Suhrabi Z, Akbari M. Prevalence and predictive factors of sexual dysfunction in Iranian women: univariate and multivariate logistic regression analyses. Korean J Fam Med. 2016 Sep;37(5):293-8, https://doi.org/10.4082/ kjfm.2016.37.5.293. PubMed PMID: 27688863; PubMed Central PMCID: PMC5039121.

30. Laumann EO, Paik A, Rosen RC. Sexual dysfunction in the United States: prevalence and predictors. JAMA. 1999 Feb; 281(6):537-44, https://doi.org/10.1001/jama.281.6.537. PubMed PMID: 10022110.

31. Dunn KM, Croft PR, Hackett GI. Association of sexual problems with social, psychological, and physical problems in men and women: a cross sectional population survey. J Epidemiol Community Health. 1999 Mar;53(3):144-8, https://doi.org/ 10.1136/jech.53.3.144. PubMed PMID: 10396490; PubMed Central PMCID: PMC1756846.

32. Dunn KM, Croft PR, Hackett GI. Sexual problems: a study of the prevalence and need for health care in the general population. Fam Pract. 1998 Dec;15(6):519-24, https://doi.org/ 10.1093/fampra/15.6.519. PubMed PMID: 10078790. 
33. Dunne MP, Martin NG, Bailey JM, Heath AC, Bucholz KK, Madden PA, et al. Participation bias in a sexuality survey: psychological and behavioural characteristics of responders and non-responders. Int J Epidemiol. 1997 Aug;26(4):844-54. PubMed PMID: 9279618.

34. Davidson K DC, Norton L. Religiosity and the sexuality of women: sexual behavior and sexual satisfaction revisited. J Sex Res. 1995;32:235-43, https://doi.org/10.1080/002244995095 51794

35. Mercer CH, Fenton KA, Johnson AM, Copas AJ, Macdowall W, Erens B, et al. Who reports sexual function problems? Empirical evidence from Britain's 2000 National Survey of Sexual Attitudes and Lifestyles. Sex Transm Infect. 2005 Oct;81 (5):394-9, https://doi.org/10.1136/sti.2005.015149. PubMed PMID: 16199738; PubMed Central PMCID: PMC1745042.

36. Casper RC, Redmond DE, Katz MM, Schaffer CB, Davis JM, Koslow SH. Somatic symptoms in primary affective disorder. Presence and relationship to the classification of depression. Arch Gen Psychiatry. 1985 Nov;42(11):1098-104, https://doi. org/10.1001/archpsyc.1985.01790340082012. PubMed PMID: 3863548.

37. Mathew RJ, Weinman ML. Sexual dysfunctions in depression. Arch Sex Behav. 1982 Aug;11(4):323-8, https://doi.org/ 10.1007/bf01541593. PubMed PMID: 7149967.

38. Angst J. Sexual problems in healthy and depressed persons. Int Clin Psychopharmacol. 1998 Jul;13 Suppl 6:S1-4, https://doi. org/10.1097/00004850-199807006-00001. PubMed PMID: 9728667.

39. Rissel CE, Richters J, Grulich AE, de Visser RO, Smith AM. Sex in Australia: selected characteristics of regular sexual relationships. Aust N Z J Public Health. 2003;27(2):124-30, https://doi.org/10.1111/j.1467-842x.2003.tb00799.x. PubMed PMID: 14696702.

40. Kadri N, McHichi Alami KH, McHakra Tahiri S. Sexual dysfunction in women: population based epidemiological study. Arch Womens Ment Health. 2002 Oct;5(2):59-63, https://doi. org/10.1007/s00737-002-0141-7. PubMed PMID: 12510200.

41. Gracia CR, Sammel MD, Freeman EW, Liu L, Hollander L, Nelson DB. Predictors of decreased libido in women during the late reproductive years. Menopause. 2004 Mar-Apr;11(2):14450, https://doi.org/10.1097/01.GME.0000082147.01218.CF. PubMed PMID: 15021443.

42. Barlow DH, Cardozo LD, Francis RM, Griffin M, Hart DM, Stephens E, et al. Urogenital ageing and its effect on sexual health in older British women. Br J Obstet Gynaecol. 1997 Jan;104(1):87-91, https://doi.org/10.1111/j.1471-0528.1997. tb10655.x. PubMed PMID: 8988703.

43. Bretschneider JG, McCoy NL. Sexual interest and behavior in healthy 80- to 102-year-olds. Arch Sex Behav. 1988 Apr; 17(2):109-29, https://doi.org/10.1007/bf01542662. PubMed PMID: 3395224.

44. Hayes R, Dennerstein L. The impact of aging on sexual function and sexual dysfunction in women: a review of populationbased studies. J Sex Med. 2005 May;2(3):317-30, https://doi. org/10.1111/j.1743-6109.2005.20356.x. PubMed PMID: 16422862.

45. Jamali S, Rahmanian A, Javadpour S. Examining the sexual function and related attitudes among aged women: a crosssectional study. Int J Reprod Biomed (Yazd). 2016 Jan;14(1):2938. PubMed PMID: 27141546; PubMed Central PMCID: PMC4837921.

46. Peeyananjarassri K, Liabsuetrakul T, Soonthornpun K, Choobun T, Manopsilp P. Sexual functioning in postmenopausal women not taking hormone therapy in the Gynecological and Menopause Clinic, Songklanagarind Hospital measured by Female Sexual Function Index questionnaire. J Med Assoc Thai. 2008 May;91(5):625-32. PubMed PMID: 18672623.

47. Lindau ST, Schumm LP, Laumann EO, Levinson W, O'Muircheartaigh CA, Waite LJ. A study of sexuality and health among older adults in the United States. N Engl J Med. 2007 Aug;357(8):762-74, https://doi.org/10.1056/NEJMoa06 7423. PubMed PMID: 17715410; PubMed Central PMCID: PMC2426743.

48. Althof SE, Leiblum SR, Chevret-Measson M, Hartmann U, Levine SB, McCabe M, et al. Psychological and interpersonal dimensions of sexual function and dysfunction. J Sex Med. 2005 Nov;2(6):793-800, https://doi.org/10.1111/j.1743-6109. 2005.00145.x. PubMed PMID: 16422804.

Sažetak

\section{SEKSUALNA FUNKCIJA ZDRAVIH ŽENA U ISTOČNOJ HRVATSKOJ}

\section{Milić Vranješ, J. Jakab, M. Ivandić, S. Šijanović i L. Zibar}

Cilj je bio procijeniti seksualnu funkciju zdravih žena u Hrvatskoj i mogući utjecaj depresije, anksioznosti i sociodemografskih čimbenika. Ukupno 204 zdrave žene ispunile su sociodemografski upitnik, Upitnik o zdravlju pacijenata-9, ljestvicu anksioznosti GAD-7 i Indeks ženske seksualne funkcije (FSFI). Gotovo polovica naših ispitanica (47,1\%) postigla je rezultat FSFI niži od 26,55, što označava određeni stupanj seksualne disfunkcije. Naši rezultati ukazuju na problem koji još uvijek nije prepoznat, a to je seksualna disfunkcija žena u Hrvatskoj. Ovom pitanju mora se dati više prostora u istraživanju i javnosti.

Ključne riječi: Ženska osoba; Hrvatska; Seksualna disfunkcija, fiziološka; Depresija; Anksioznost; Bolesničko zdravlje, upitnik 